Methods of Analysis by the U.S. Geological Survey National Water Quality Laboratory-A Method Supplement for the Determination of Fipronil and Degradates in Water by Gas Chromatography/Mass Spectrometry

Open-File Report 02-462

U.S. Department of the Interior

U.S. Geological Survey 


\section{Methods of Analysis by the U.S. Geological Survey National Water Quality Laboratory-A Method Supplement for the Deter- mination of Fipronil and Degradates in Water by Gas Chroma- tography/Mass Spectrometry}

By James E. Madsen, Mark W. Sandstrom, and Steven D. Zaugg

U.S. Geological Survey

Open-File Report 02-462

U.S. Geological Survey Method O-1126-02

Supplementary Laboratory Method (Schedules) 2001 and 2010 


\section{U.S. DEPARTMENT OF THE INTERIOR}

Gale A. Norton, Secretary

U.S. GEOLOGICAL SURVEY

Charles G. Groat, Director

The use of trade, product, or firm names in this report is for descriptive purposes only and does not imply endorsement by the U.S. Government.

For additional information write to:

U.S. Geological Survey

Chief, National Water Quality Laboratory

Box 25046, Mail Stop 407

Federal Center

Denver, CO 80225-0046
Copies of this report can be purchased from:

U.S. Geological Survey

Branch of Information Services

Box 25286

Federal Center

Denver, CO 80225-0286 


\section{CONTENTS}

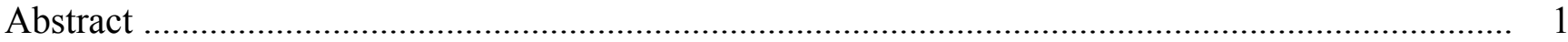

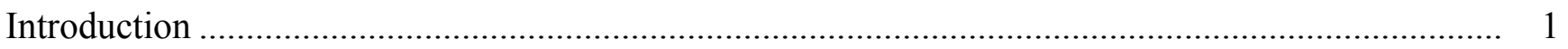

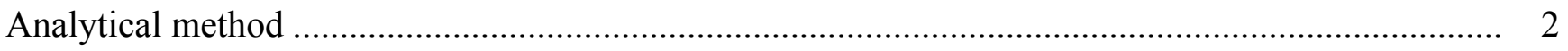

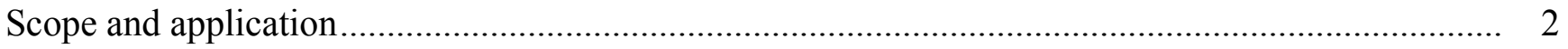

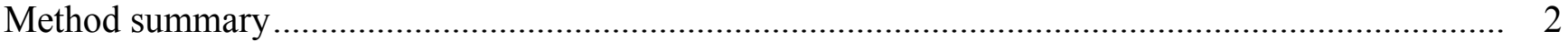

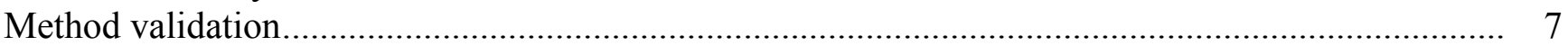

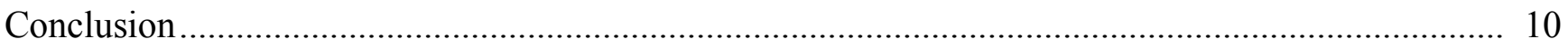

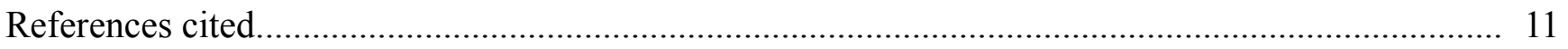

\section{FIGURE}

1. Graph showing selected-ion chromatogram of pesticides and degradates in a 1.0-nanogram-per-microliter $(\mathrm{ng} / \mu \mathrm{L})$ standard solution

\section{TABLES}

1. Compound name, use, pesticide class, parameter code, Chemical Abstracts Service (CAS) registry number, molecular weight, and remark code for fipronil and degradates

2. Compound name, manufacturer code, structural name, structure, and formula for fipronil and degradates.....

3. Compound retention time, quantitation ion, confirmation ions, monitor ion, and remark code 5

4. Mean bias and variability of spike recovery data for 10 replicates with compounds spiked at 0.1 and 1.0 microgram per liter in reagent water, ground water (Jefferson County mountain well), and surface water (South Platte River at Denver, Colo.).

5. Recovery data from interlaboratory comparison study for three replicates spiked at 0.02 and 0.2 microgram per liter

6. Initial method detection limits calculated from recovery variability data using 10 replicate reagent-water samples with compound concentrations spiked at 0.01 microgram per liter 
CONVERSION FACTORS AND ABBREVIATED WATER-QUALITY UNITS

\begin{tabular}{rcl}
\hline Multiply & By & To obtain \\
\hline gram $(\mathrm{g})$ & $3.53 \times 10^{-2}$ & ounce, avoirdupois \\
$\operatorname{liter}(\mathrm{L})$ & $2.64 \times 10^{-1}$ & gallon \\
micrometer $(\mu \mathrm{m})$ & $3.94 \times 10^{-5}$ & inch \\
\hline
\end{tabular}

Degrees Celsius $\left({ }^{\circ} \mathrm{C}\right)$ may be converted to degrees Fahrenheit $\left({ }^{\circ} \mathrm{F}\right)$ by using the following equation:

$$
{ }^{\circ} \mathrm{F}=9 / 5\left({ }^{\circ} \mathrm{C}\right)+32 .
$$

\section{ABBREVIATIONS AND ACRONYMS}

C-18 octadecylsilyl

CAS Chemical Abstracts Service

CCV continuing calibration verification

GC gas chromatography

GC/MS gas chromatography/mass spectrometry

HPLC high-performance liquid chromatography

MDL method detection limit

$\mathrm{m} / \mathrm{z} \quad$ mass-to-charge ratio

$\mathrm{mg} / \mathrm{L} \quad$ milligram per liter

MRL minimum reporting level

NAWQA National Water-Quality Assessment Program

$\mathrm{ng} / \mu \mathrm{L} \quad$ nanogram per microliter

NWQL National Water Quality Laboratory

SIM selected-ion monitoring

SPE solid-phase extraction

USGS U.S. Geological Survey

$\mu \mathrm{g} / \mathrm{L} \quad$ microgram per liter

$\mu \mathrm{S} / \mathrm{cm} \quad$ microsiemens per centimeter at 25 degrees Celsius

\section{ACKNOWLEDGMENTS}

\section{Technical Review}

Dr. James A. Hetrick, U.S. Environmental Protection Agency

Stanley C. Skrobialowski, U.S. Geological Survey

Peter F. Rogerson, U.S. Geological Survey

William T. Foreman, U.S. Geological Survey

Mike P. Schroeder, U.S. Geological Survey

\section{Editorial Review}

Jon W. Raese, U.S. Geological Survey 


\title{
Methods of Analysis by the U.S. Geological Survey National Water Quality Laboratory-A Method Supplement for the Determination of Fipronil and Degradates in Water by Gas Chromatography/Mass Spectrometry
}

\author{
By James E. Madsen, Mark W. Sandstrom, and Steven D. Zaugg
}

\begin{abstract}
A method for the isolation and determination of fipronil and four of its degradates has been developed. This method adapts an analytical method created by the U.S. Geological Survey National Water Quality Laboratory in 1995 for the determination of a broad range of high-use pesticides typically found in filtered natural-water samples. In 2000, fipronil and four of its degradates were extracted, analyzed, and validated using this method. The recoveries for these five compounds in reagent-water samples fortified at 1 microgram per liter $(\mu \mathrm{g} / \mathrm{L})$ averaged 98 percent. Initial method detection limits averaged $0.0029 \mu \mathrm{g} / \mathrm{L}$. The performance of these five new compounds is consistent with the performance of the compounds in the initial method, making it possible to include them in addition to the other 41 pesticides and pesticide degradates in the original method.
\end{abstract}

\section{INTRODUCTION}

Fipronil is a phenylpyrazole insecticide discovered in 1987 by Rhône-Poulenc researchers in Ongar, England (Rhône-Poulenc, Inc., 1996). It was introduced in the United States in 1996 for use in animal health care, indoor pest control, and golf course and commercial turf care (National Pesticide Telecommunications Network, 1997). Fipronil is an emerging insecticide in the pesticide market and is registered for use as an alternative to chlorpyrifos in pet products, and for control of home pests, termites (U.S. Environmental Protection Agency, 2002), fire ants, mole crickets, and field corn pests (U.S. Environmental Protection Agency, 2001). The use of carbofuran for the control of the water rice weevil was banned in the late 1990 's, and fipronil is one of the insecticides registered as a replacement (Stout and others, 2002, p. 20-21). U.S. Geological Survey (USGS) scientists in Louisiana were conducting a National Water-Quality Assessment Program (NAWQA) agricultural study on the environmental effects of land use in the Mermentau River Basin and wanted to include fipronil and its degradates in the study after learning of a high incidence of crawfish mortality with the onset of fipronil use on rice in conjunction with unusual drought conditions. Consequently, the Louisiana District requested that the USGS National Water Quality Laboratory (NWQL) develop a custom method for fipronil and its degradates.

There are few published analytical methods for the determination of fipronil and its degradates. Hainzl and Casida (1996) used gas chromatography/mass spectrometry (GC/MS) for determination of fipronil and degradates in plant and tissue extracts. Mulrooney and others (1998) used a high-performance liquid chromatography (HPLC) method with ultraviolet diode array detection for determination of fipronil and degradates on leaf surfaces. Ngim and Crosby (2001) used an octadecylsilyl (C-18) solid-phase extraction and $\mathrm{GC}$ with thermionic specific detector method to determine fipronil residues in water and soil samples from rice fields. Vilchez and others (2001) recently described a solid-phase microextraction method with GC/MS for the determination of fipronil in water, soil, and urine. 
This report describes the adaptation of a wellestablished method for the determination of fipronil and four degradates. The NWQL developed the analytical method (Zaugg and others, 1995) in response to a request by NAWQA for a broad-spectrum method to determine the presence and distribution of pesticides. New compounds added to the method are listed in table 1. Fipronil amide (Rhône-Poulenc Agro 200766) also was tested, but was not detected by GC/MS using the instrumental conditions of the analytical method. Structures for these compounds are shown in table 2.

The fipronil degradates are important environmentally because some are more toxic to nonselected species than the parent compound. Desulfinylfipronil is formed through photodegradation in water and on soil. Fipronil sulfide is formed through degradation in soil and water under anaerobic conditions and is more toxic than fipronil to freshwater invertebrates. Fipronil sulfone is formed through aerobic soil metabolism and is much more toxic to avian species and freshwater fish and invertebrates than the parent compound. Fipronil amide is the major product of alkaline hydrolysis (U.S. Environmental Protection Agency, 1996).

\section{ANALYTICAL METHOD \\ Organic Compounds and Parameter Codes: Pesticides, filtered, and gas chromatography/ mass spectrometry, O-1126-02 (see table 1)}

\section{SCOPE AND APPLICATION}

This report describes supplementary information for fipronil and four degradates in USGS method O-1126-95 (Zaugg and others, 1995). A description of these five compounds and method validation data for them are included.

\section{METHOD SUMMARY}

Samples are collected and filtered onsite by using glass-fiber filters $(0.7-\mu \mathrm{m}$ nominal pore diameter) as described by Sandstrom (1995). At the NWQL or at the field site, samples are prepared for analysis by C-18 solid-phase extraction (SPE), and compounds are determined by capillary-column quadrupole GC/MS using positive-ion electron-impact selected-ion monitoring (SIM). A detailed description of the

Table 1. Compound name, use, pesticide class, parameter code, Chemical Abstracts Service (CAS) registry number, molecular weight, and remark code for fipronil and degradates

[P-code, National Water Information System parameter code; CASRN, Chemical Abstracts Service Registry Number; MW, molecular weight; I, insecticide; E, estimated remark code; Deg, degradate; N/A, not available; -, not applicable]

\begin{tabular}{|c|c|c|c|c|c|c|}
\hline Compound name & Use & Class & P-code & CASRN & MW & $\begin{array}{c}\text { Remark } \\
\text { code }\end{array}$ \\
\hline Fipronil $^{1}$ & I & pyrazole & 62166 & $120068-37-3$ & 437.1 & $\mathrm{E}$ \\
\hline Desulfinylfipronil & Deg & pyrazole & 62170 & $\mathrm{~N} / \mathrm{A}$ & 389.1 & - \\
\hline Desulfinylfipronil amide $^{1}$ & Deg & pyrazole & 62169 & $\mathrm{~N} / \mathrm{A}$ & 407.1 & $\mathrm{E}$ \\
\hline Fipronil sulfide & Deg & pyrazole & 62167 & $120067-83-6$ & 421.1 & - \\
\hline Fipronil sulfone & Deg & pyrazole & 62168 & $120068-36-2$ & 453.1 & - \\
\hline
\end{tabular}

\footnotetext{
${ }^{1}$ Concentration is always estimated because of possible matrix effect.
} 
Table 2. Compound name, manufacturer code, structural name, structure, and formula for fiponil and degradates

[CA, Chemical Abstracts]

\begin{tabular}{|c|c|c|c|c|}
\hline Compound name & $\begin{array}{l}\text { Manufacturer } \\
\text { code }^{1}\end{array}$ & CA name & Structure & Formula \\
\hline Fipronil & MB 46030 & $\begin{array}{l}\text { 5-Amino-3-cyano-1-(2,6-dichloro- } \\
\text { 4-trifluoromethylphenyl)-4-trifluor- } \\
\text { omethylsulfinylpyrazole }\end{array}$ & & $\mathrm{C}_{12} \mathrm{H}_{4} \mathrm{Cl}_{2} \mathrm{~F}_{6} \mathrm{~N}_{4} \mathrm{OS}$ \\
\hline Desulfinylfipronil & MB 46513 & $\begin{array}{l}\text { 5-Amino-3-cyano-1-(2,6-dichloro- } \\
\text { 4-trifluoromethylphenyl)-4-trifluor- } \\
\text { omethylpyrazole }\end{array}$ & & $\mathrm{C}_{12} \mathrm{H}_{4} \mathrm{Cl}_{2} \mathrm{~F}_{6} \mathrm{~N}_{4}$ \\
\hline Desulfinylfipronil amide & RPA 105048 & $\begin{array}{l}\text { 5-Amino-3-carbamoyl-1-(2,6- } \\
\text { dichloro-4-trifluoromethylphenyl)- } \\
\text { 4-trifluoromethylpyrazole }\end{array}$ & & $\mathrm{C}_{12} \mathrm{H}_{6} \mathrm{Cl}_{2} \mathrm{~F}_{6} \mathrm{~N}_{4} \mathrm{O}$ \\
\hline Fipronil amide ${ }^{2}$ & RPA 200766 & $\begin{array}{l}\text { 5-Amino-3-carbamoyl-1-(2,6- } \\
\text { dichloro-4-trifluoromethylphenyl)-4- } \\
\text { trifluoromethylsulfinylpyrazole }\end{array}$ & & $\mathrm{C}_{12} \mathrm{H}_{6} \mathrm{Cl}_{2} \mathrm{~F}_{6} \mathrm{~N}_{4} \mathrm{O}_{2} \mathrm{~S}$ \\
\hline
\end{tabular}


- Table 2. Compound name, manufacturer code, structural name, structure, and formula for fiponil and degradates—Continued

ble 2. Compound name, manufacturer code, structural name, structure, and formula for fiponil and degradates - Continued

\begin{tabular}{|c|c|c|c|c|}
\hline Compound name & $\begin{array}{l}\text { Manufacturer } \\
\text { code }^{1}\end{array}$ & CA name & Structure & Formula \\
\hline Fipronil sulfide & MB 45950 & $\begin{array}{l}\text { 5-Amino-3-cyano-1-(2,6-dichloro-4- } \\
\text { trifluoromethylphenyl)-4-trifluor- } \\
\text { omethyl-thio-pyrazole }\end{array}$ & & $\mathrm{C}_{12} \mathrm{H}_{4} \mathrm{Cl}_{2} \mathrm{~F}_{6} \mathrm{~N}_{4} \mathrm{~S}$ \\
\hline Fipronil sulfone & MB 46136 & $\begin{array}{l}\text { 5-Amino-3-cyano-1-(2,6-dichloro- } \\
\text { 4-trifluoromethylphenyl)-4- } \\
\text { trifluoromethylsulfonylpyrazole }\end{array}$ & & $\mathrm{C}_{12} \mathrm{H}_{4} \mathrm{Cl}_{2} \mathrm{~F}_{6} \mathrm{~N}_{4} \mathrm{O}_{2} \mathrm{~S}$ \\
\hline
\end{tabular}

1"MB" and "RPA" manufacturer codes are listed for easy cross-reference to other sources of information. "MB" refers to "May Baker" and "RPA" refers to "Rhône-Poulenc Agro."

${ }^{2}$ Fipronil amide is not included in this method. 
method (including the equipment, reagents, sampling protocol, instrument calibration, SPE procedure, and sample analysis) is reported in Zaugg and others (1995).

A few substantial changes were made to the original method after its publication. The SPE elution solvent was changed from hexane-isopropanol to ethyl acetate, the upper concentration range was extended by dilution, acetochlor was added (Lindley and others, 1996), and terbuthylazine was deleted as a surrogate.

The compound names, approximate retention times, mass-spectral quantitation and two confirmation ions, and the polynuclear aromatic hydrocarbon internal-standard reference compound used for quantitation are listed in table 3. An example of the separation and peak shape of fipronil and degradates is shown in a total ion chromatogram of a $1.0-\mathrm{ng} / \mu \mathrm{L}$ standard solution in figure 1 . Positive identification of a compound requires it to elute within 0.1 minute $( \pm 6$ seconds) of its expected retention-time window based on calibration standard injections. Furthermore, the maxima of the quantitation and two associated confirmation ion peaks should be within 0.01 minute of each other. The sample spectra and ion abundance ratios also are inspected to determine if they match the internal-standard reference compound. (A monitor ion for each compound for optional further confirmation also is listed in table 3.)

After qualitative criteria are met, the compound concentration is determined by calculating the relative response of the quantitation ion to the corresponding internal-standard reference compound (table 3 ) and comparing it with a seven-point calibration curve of relative responses equivalent to the range from 0.001 to $4.0 \mu \mathrm{g} / \mathrm{L}$.

At least one fortified laboratory reagent-water spike sample at $0.1 \mu \mathrm{g} / \mathrm{L}$ and one laboratory reagentwater blank sample are analyzed with each set of up to 10 environmental samples. Two surrogate compounds (table 3) are added to all samples at $0.1 \mu \mathrm{g} / \mathrm{L}$ prior to extraction to monitor the sample-specific performance.

Table 3. Compound retention time, quantitation ion, confirmation ions, monitor ion, and remark code

[Compounds are listed in order of retention time. min, minutes; $\mathrm{m} / \mathrm{z}$, mass-to-charge ratio; -, not used; E, estimated remark code; IS, internal standard]

\begin{tabular}{|c|c|c|c|c|c|c|}
\hline Compound name & $\begin{array}{c}\text { Retention } \\
\text { time } \\
\text { (min) }\end{array}$ & $\begin{array}{c}\text { Quantitation } \\
\text { ion } \\
(\mathbf{m} / \mathbf{z})\end{array}$ & $\begin{array}{c}\text { Confirmation } \\
\text { ion } \\
(\mathbf{m} / \mathbf{z})\end{array}$ & $\begin{array}{c}\text { Confirmation } \\
\text { ion } \\
(\mathbf{m} / \mathbf{z})\end{array}$ & $\begin{array}{c}\text { Monitor } \\
\text { ion } \\
(\mathbf{m} / \mathbf{z})\end{array}$ & $\begin{array}{c}\text { Remark } \\
\text { code }\end{array}$ \\
\hline Desulfinylfipronil & 25.63 & 388 & 390 & 333 & 369 & - \\
\hline Fipronil sulfide & 28.11 & 351 & 353 & 255 & 257 & - \\
\hline Fipronil & 28.48 & 367 & 213 & 369 & 215 & $\mathrm{E}$ \\
\hline Fipronil sulfone & 30.15 & 383 & 255 & 385 & 257 & - \\
\hline Desulfinylfipronil amide & 30.14 & 406 & 390 & 408 & 392 & $\mathrm{E}$ \\
\hline \multicolumn{7}{|l|}{ Surrogates } \\
\hline alpha-HCH- $d_{6}$ & 22.73 & 224 & 222 & 226 & - & - \\
\hline Diazinon- $d_{10}$ & 23.84 & 183 & 153 & 138 & - & - \\
\hline \multicolumn{7}{|c|}{ Internal-standard reference $^{1}$} \\
\hline Phenanthrene- $d_{10}$ (IS2) & 24.69 & 188 & 186 & - & - & - \\
\hline
\end{tabular}

\footnotetext{
${ }^{1}$ Fipronil and degradates are all referenced to polynuclear aromatic hydrocarbon internal-standard reference compound
} IS2. 


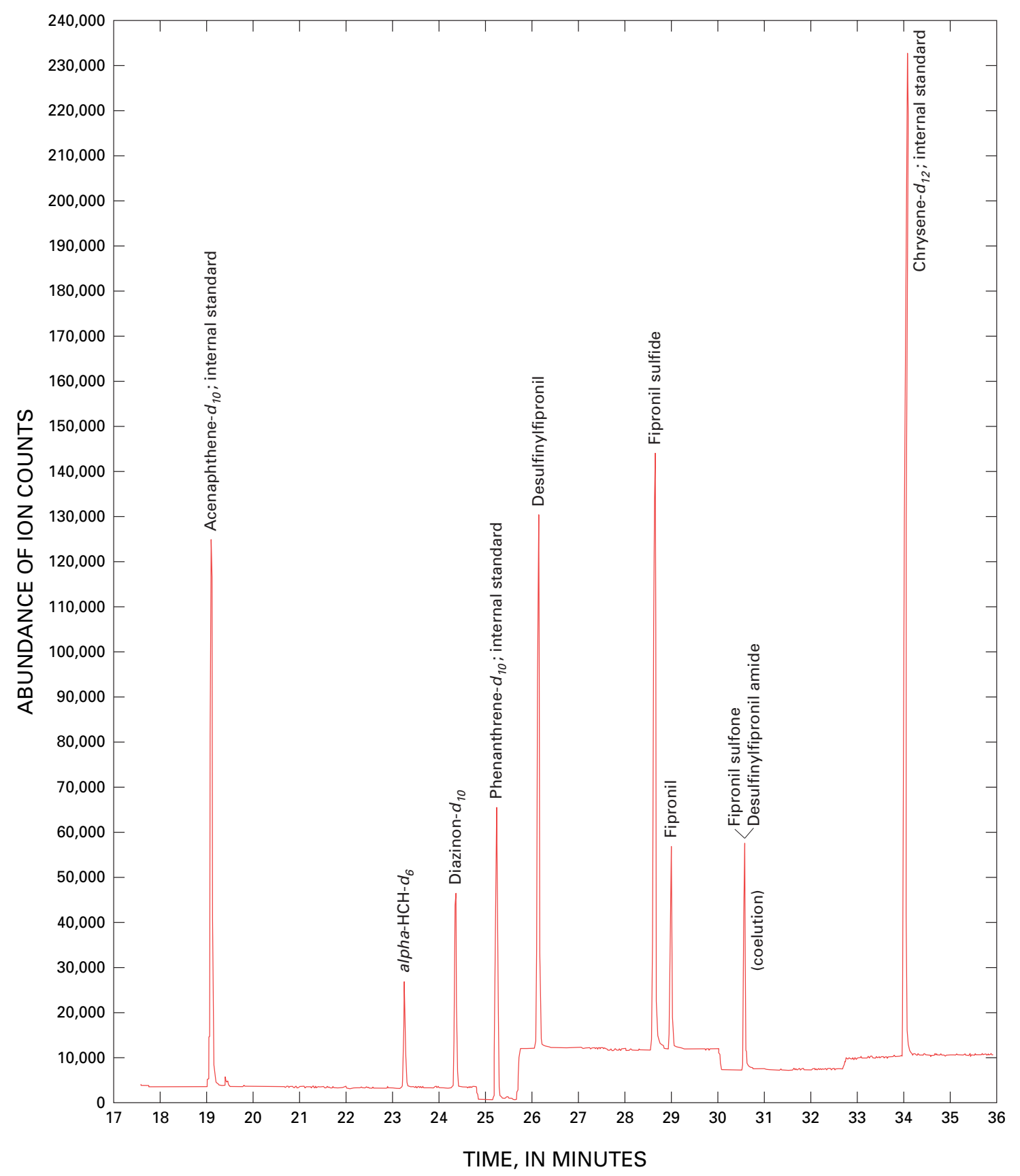

Figure 1. Seclected-ion chromatogram of pesticides and degradates in a 1.0-nanogram-per-microliter $(\mathrm{ng} / \mu \mathrm{L}) \mathrm{standard}$ solution. 


\section{METHOD VALIDATION}

Pure materials for preparing standard solutions were obtained from the U.S. Environmental Protection Agency Pesticide Repository (Fort Meade, Md.) and Aventis Corporation (Research Triangle, N.C.). Reagent water was prepared by filtration, deionization, and ultraviolet radiation using a Solution $2000^{\circledR}$ Type I Reagent Grade Water Purification System (Solution Consultants Inc., Jasper, Ga.). A reagent-water sample, a ground-water sample collected from a domestic well in Jefferson County, Colo., and a surface-water sample collected from the South Platte River at Denver, Colo., were used to test method performance. Ancillary water-quality information was not measured in these particular samples.

Historical water-quality data (1998-2001) from the South Platte River site (U.S. Geological Survey, 2002) indicate that dissolved organic carbon levels ranged from 3.9 to $10 \mathrm{mg} / \mathrm{L}$ (median $5.0 \mathrm{mg} / \mathrm{L}$ ), specific conductance ranged from 323 to $1,280 \mu \mathrm{S} / \mathrm{cm}$ at $25^{\circ} \mathrm{C}$ (median $646 \mu \mathrm{S} / \mathrm{cm}$ ), and $\mathrm{pH}$ ranged from 7.7 to 9.0 (median pH 8.2). Historical water-quality data (19981999) from the ground-water site (Schwartz, 2001) indicate that dissolved organic carbon was less than 0.1 $\mathrm{mg} / \mathrm{L}$, specific conductance ranged from 365 to 374 $\mu \mathrm{S} / \mathrm{cm}$ (median $372 \mu \mathrm{S} / \mathrm{cm}$ ), and $\mathrm{pH}$ ranged from 7.54 to 7.62 (median pH 7.6). The surface- and groundwater samples were filtered into 1-L sample bottles prior to extraction according to the method protocol. Each sample matrix was divided into two sets of 11 subsamples. A fortification solution in methanol containing fipronil and its degradates was prepared at two concentrations. Next, 10 subsamples from each matrix were fortified at a low concentration $(0.1 \mu \mathrm{g} / \mathrm{L})$ and extracted and analyzed, and 10 subsamples from each matrix were fortified at a higher concentration $(1.0 \mu \mathrm{g} / \mathrm{L})$ and extracted and analyzed. In addition, two subsamples from each matrix were extracted and analyzed (unfortified) to determine the presence of any background contamination. All of the subsamples, including those used in the study that follows to determine the method detection limit (MDL), were placed in one analytical instrument sequence in random order, with a continuing calibration verification standard following each 12 subsamples. No background contamination was detected in the unfortified samples.

Performance in different matrices: Average percent recovery of all method compounds for shortterm single-operator results in reagent-water samples fortified at $1.0 \mu \mathrm{g} / \mathrm{L}$ was $98 \pm 6$ percent relative standard deviation. Average recovery for these compounds in the ground-water subsamples fortified at $1.0 \mu \mathrm{g} / \mathrm{L}$ was $88 \pm 4$ percent relative standard deviation. Average recovery for these compounds in the surface-water subsamples fortified at $1.0 \mu \mathrm{g} / \mathrm{L}$ was $102 \pm 2$ percent relative standard deviation.

At the low concentration, there were more significant differences in recovery for some of the compounds in the different matrices compared to the $1.0-\mu \mathrm{g} / \mathrm{L}$ fortification. Fipronil and desulfinylfipronil amide recoveries (table 4) were about 190 percent in the surface-water subsamples fortified at $0.1 \mu \mathrm{g} / \mathrm{L}$. Recoveries for the other compounds were close to 100 percent, comparable to the high-concentration samples. This enhancement of recovery in surface-water samples also was evident in other samples analyzed as part of the method validation.

In 2000, the NWQL participated in an interlaboratory comparison study (table 5). Surfacewater samples were collected from the Tchefuncte River near Covington, La., more than 100 miles east of the NAWQA agricultural study area, where fipronil and degradates were not expected. These surfacewater samples, fortified at $0.02 \mu \mathrm{g} / \mathrm{L}$ and analyzed by the NWQL, also showed the enhanced recovery for fipronil (163 percent). Desulfinylfipronil amide was not included in the spike mix. No unfortified samples were analyzed in this comparison study.

One of the laboratories in the interlaboratory comparison study used a liquid chromatography tandem mass spectrometry analytical method for recoveries of fipronil and degradates that were close to 100 percent in the same subsamples. This difference in recovery might be caused by decreased degradation of fipronil and desulfinylfipronil amide in surface-water extracts after injection into the heated injection port of the gas chromatograph. Injection-port degradation of fipronil and desulfinylfipronil amide in reagent- and ground-water extracts is comparable to that for calibration standards. The surface-water matrix appears to deactivate active sites in the injection port or column resulting in a surface-water matrix effect. This effect is more apparent at lower concentrations than higher concentrations (table 4). Other GC methods note degradation in the injection port and the need for required maintenance and quality-control samples for other compounds (Foreman, 1997; Munch, 1995). 


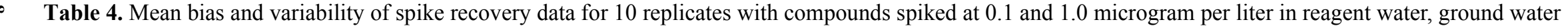
(Jefferson County mountain well), and surface water (South Platte River at Denver, Colo.)

\begin{tabular}{|c|c|c|c|c|c|c|c|c|}
\hline \multirow{2}{*}{$\begin{array}{l}\text { Compound } \\
\text { name }\end{array}$} & \multirow{2}{*}{$\begin{array}{c}\text { Spike } \\
\text { amount } \\
(\mu \mathrm{g} / \mathrm{L})\end{array}$} & \multicolumn{3}{|c|}{ Mean percent recovery } & \multicolumn{3}{|c|}{ Percent RSD } & \multirow{2}{*}{$\begin{array}{c}\text { Remark } \\
\text { code }\end{array}$} \\
\hline & & $\begin{array}{c}\text { Reagent } \\
\text { water }\end{array}$ & $\begin{array}{c}\text { Ground } \\
\text { water }\end{array}$ & $\begin{array}{c}\text { Surface } \\
\text { water }\end{array}$ & $\begin{array}{c}\text { Reagent } \\
\text { water }\end{array}$ & $\begin{array}{c}\text { Ground } \\
\text { water }\end{array}$ & $\begin{array}{c}\text { Surface } \\
\text { water }\end{array}$ & \\
\hline \multirow[t]{2}{*}{ Fipronil } & 1.0 & 94.2 & 85.1 & 108 & 7.57 & 5.14 & 0.65 & $\mathrm{E}$ \\
\hline & .1 & 115 & 108 & 191 & 9.45 & 9.65 & 4.23 & $\mathrm{E}$ \\
\hline \multirow[t]{2}{*}{ Desulfinylfipronil } & 1.0 & 107 & 94.4 & 102 & 4.30 & 3.74 & 2.16 & - \\
\hline & .1 & 113 & 100 & 123 & 5.77 & 5.60 & 2.75 & - \\
\hline \multirow[t]{2}{*}{ Desulfinylfipronil amide } & 1.0 & 99.3 & 89.6 & 106 & 6.00 & 4.26 & .83 & $\mathrm{E}$ \\
\hline & .1 & 112 & 101 & 187 & 14.2 & 13.5 & 2.33 & $\mathrm{E}$ \\
\hline \multirow[t]{2}{*}{ Fipronil sulfide } & 1.0 & 99.6 & 89.3 & 99.0 & 4.83 & 4.24 & 2.66 & - \\
\hline & .1 & 103 & 91.3 & 110 & 8.25 & 6.06 & 4.90 & - \\
\hline \multirow[t]{2}{*}{ Fipronil sulfone } & 1.0 & 88.1 & 83.6 & 93.2 & 5.96 & 5.02 & 4.61 & - \\
\hline & .1 & 85.2 & 80.1 & 106 & 11.5 & 8.73 & 7.75 & - \\
\hline \multicolumn{9}{|l|}{ Surrogate compounds } \\
\hline alpha-HCH- $d_{6}$ & .1 & 98.9 & 92.9 & 102 & 4.18 & 5.32 & 3.80 & - \\
\hline Diazinon- $d_{10}$ & .1 & 99.7 & 88.1 & 112 & 5.52 & 4.66 & 3.53 & - \\
\hline
\end{tabular}


Table 5. Recovery data from interlaboratory comparison study for three replicates spiked at 0.02 and 0.2 microgram per liter [ $\mu \mathrm{g} / \mathrm{L}$, microgram per liter; USGS, U.S. Geological Survey; --, not applicable; E, estimated remark code; -, not spiked]

\begin{tabular}{|c|c|c|c|c|c|c|c|c|}
\hline \multirow{2}{*}{$\begin{array}{l}\text { Compound } \\
\text { name }\end{array}$} & \multirow{2}{*}{$\begin{array}{c}\text { Spike } \\
\text { amount } \\
(\mu \mathrm{g} / \mathrm{L})\end{array}$} & \multicolumn{2}{|c|}{$\begin{array}{c}\text { Mean percent recovery } \\
\text { laboratory } 1^{1}\end{array}$} & \multicolumn{2}{|c|}{$\begin{array}{c}\text { Mean percent recovery } \\
\text { laboratory } 2^{2}\end{array}$} & \multicolumn{2}{|c|}{$\begin{array}{c}\text { Mean percent recovery } \\
\text { USGS }\end{array}$} & \multirow{2}{*}{$\begin{array}{l}\text { Remark } \\
\text { code }\end{array}$} \\
\hline & & $\begin{array}{l}\text { Reagent } \\
\text { water }\end{array}$ & $\begin{array}{l}\text { Surface } \\
\text { water }\end{array}$ & $\begin{array}{l}\text { Reagent } \\
\text { water }\end{array}$ & $\begin{array}{l}\text { Surface } \\
\text { water }\end{array}$ & $\begin{array}{l}\text { Reagent } \\
\text { water }\end{array}$ & $\begin{array}{l}\text { Surface } \\
\text { water }^{3}\end{array}$ & \\
\hline \multirow[t]{2}{*}{ Fipronil } & 0.20 & 106 & -- & 87.5 & -- & 112 & -- & $\mathrm{E}$ \\
\hline & .02 & 97.3 & 95.8 & 158 & 128 & 114 & 163 & $\mathrm{E}$ \\
\hline \multirow[t]{2}{*}{ Desulfinylfipronil } & .20 & 109 & -- & 126 & -- & 115 & -- & -- \\
\hline & .02 & 104 & 96.5 & 146 & 108 & 107 & 112 & -- \\
\hline Desulfinylfipronil amide ${ }^{4}$ & - & - & - & - & - & - & - & $\mathrm{E}$ \\
\hline \multirow[t]{2}{*}{ Fipronil sulfide } & .20 & 104 & -- & 111 & -- & 104 & -- & -- \\
\hline & .02 & 100 & 95.9 & 145 & 115 & 90.7 & 104 & -- \\
\hline \multirow[t]{2}{*}{ Fipronil sulfone } & .20 & 97.3 & -- & 92.4 & -- & 93.2 & -- & -- \\
\hline & .02 & 96.2 & 88.5 & 134 & 95.7 & 80.3 & 97.2 & -- \\
\hline
\end{tabular}

${ }^{1}$ Laboratory 1 used a liquid chromatography tandem mass spectrometry analytical method.

${ }^{2}$ Laboratory 2 averaged results acquired by two analytical methods: gas chromatography with electron-capture detection and gas chromatography/mass spectrometry.

${ }^{3}$ USGS surface-water mean percent recoveries were for six replicates.

${ }^{4}$ Desulfinylfipronil amide was not included in the fortification solution. 
Method detection limits: Initial MDLs were calculated (table 6) according to procedures outlined by the U.S. Environmental Protection Agency (1997) using the data for reagent-water spikes at $0.01-\mu \mathrm{g} / \mathrm{L}$ spike concentration. The MDL is defined as the minimum concentration of a substance that can be measured and reported with 99-percent confidence that the compound concentration is greater than zero (U.S. Environmental Protection Agency, 1997).

Initial MDLs range from 0.002 to $0.004 \mu \mathrm{g} / \mathrm{L}$ and average $0.0029 \mu \mathrm{g} / \mathrm{L}$, similar to MDLs calculated for the 41 compounds in the original method (Zaugg and others, 1995). The initial minimum reporting levels (MRLs; table 6) have been set to about twice the calculated initial MDLs. This precaution reduces the risk of reporting that a compound is undetected (less than the MRL), when it is actually in the sample near the MDL concentration (Childress and others, 1999). The high-use pesticide method is considered to be "information-rich" (Childress and others, 1999) because compound identifications are determined by mass spectrometry and all qualitatively identified compounds are reported, regardless of the established MRL.

Coelutions and interferences: Ions with high massto-charge $(\mathrm{m} / \mathrm{z})$ ratios were selected for identification and quantitation of fipronil and its degradates because of the high relative abundance and uniqueness of these ions. Fipronil sulfone and desulfinylfipronil amide coelute in this analysis. However, each of these compounds can be identified and quantitated by its unique ions. None of the ions in the fipronil sulfone spectrum are selected ions for desulfinylfipronil amide. The quantitation ion $\mathrm{m} / \mathrm{z} 383$ and confirmation ion $\mathrm{m} / \mathrm{z}$ 385 for fipronil sulfone are not present in the desulfinylfipronil amide spectrum. The confirmation ion $\mathrm{m} / \mathrm{z} 255$ and monitor ion $\mathrm{m} / \mathrm{z} 257$ for fipronil sulfone are present in desulfinylfipronil amide. This coelution has not caused a problem in identifying fipronil sulfone because of the two unique selected ions for fipronil sulfone. Desulfinylfipronil amide has been detected only at low concentrations in samples analyzed to date (2002).

None of the compounds included in method O1126-95 (Zaugg and others, 1995) interfere with any of the selected ions of fipronil or its degradates.

Qualification of compounds: Because fipronil and desulfinylfipronil amide appear to have matrixenhanced recovery in some matrices at low concentrations, all results for these two compounds are reported with an estimated "E" remark code. If the calculated concentration for a compound is less than either the MRL or the lowest calibration standard, then the result for that compound also is reported as estimated (Childress and others, 1999).

\section{CONCLUSION}

The broad-spectrum pesticide method of Zaugg and others (1995) that uses solid-phase extraction and gas chromatography/mass spectrometry provides an efficient means of determining fipronil and four of its degradates. With thousands of compounds and their degradates being introduced into the environment each year, it is advantageous to add new compounds to existing analytical methods. The addition of these five compounds to this method will improve the ability of scientists to evaluate the distribution, transport, and fate of fipronil in the environment.

Table 6. Initial method detection limits calculated from recovery variability data using 10 replicate reagent-water samples with compound concentrations spiked at 0.01 microgram per liter

$[\mu \mathrm{g} / \mathrm{L}$, microgram per liter; RSD, relative standard deviation; MDL, method detection limit; MRL, minimum reporting level; E, estimated remark code; -, not applicable]

\begin{tabular}{lcccccc}
\hline \multicolumn{1}{c}{ Compound name } & $\begin{array}{c}\text { Spike amount } \\
(\boldsymbol{\mu g} / \mathbf{L})\end{array}$ & $\begin{array}{c}\text { Mean } \\
\text { recovery } \\
(\boldsymbol{\mu g} / \mathbf{L})\end{array}$ & $\begin{array}{c}\text { RSD } \\
(\text { percent })\end{array}$ & $\begin{array}{c}\text { Initial } \\
\mathbf{M D L} \\
(\boldsymbol{\mu g} / \mathbf{L})\end{array}$ & $\begin{array}{c}\text { Initial } \\
\mathbf{M R L} \\
(\boldsymbol{\mu g} / \mathbf{L})\end{array}$ & $\begin{array}{c}\text { Remark } \\
\text { code }\end{array}$ \\
\hline Fipronil & 0.01 & 0.0108 & 11.2 & 0.003 & 0.007 & $\mathrm{E}$ \\
Desulfinylfipronil & .01 & .0101 & 7.1 & .002 & .004 & - \\
Desulfinylfipronil amide & .01 & .0093 & 16.6 & .004 & .009 & $\mathrm{E}$ \\
Fipronil sulfide & .01 & .0088 & 9.7 & .002 & .005 & - \\
Fipronil sulfone & .01 & .0067 & 11.3 & .002 & .005 & - \\
\hline
\end{tabular}




\section{REFERENCES CITED}

Childress, C.J.O., Foreman, W.T., Connor, B.F., and Maloney, T.J, 1999, New reporting procedures based on long-term method detection levels and some considerations for interpretations of waterquality data provided by the U. S. Geological Survey National Water Quality Laboratory: U.S. Geological Survey Open-File Report 99-193, 19 p.

Foreman, W.T., and Gates, P.M., 1997, Matrixenhanced degradation of p,p'-DDT during gas chromatographic analysis - A consideration: Environmental Science \& Technology, v. 31, p. 905-910.

Hainzl, Dominik, and Casida, J.E., 1996, Fipronil insecticide-Novel photochemical desulfinylation with retention of neurotoxicity: Proceedings of the National Academy of Sciences of the United States of America, v. 93, p. 12764-12767.

Lindley, C.E., Stewart, J.T., and Sandstrom, M.W., 1996, Determination of low concentrations of acetochlor in water by automated solid-phase extraction and gas chromatography with mass selective detection: Journal of AOAC International, v. 79, no. 4, p. 962-966.

Munch, J.W., 1995, Method 508-Determination of chlorinated pesticides in water by gas chromatography with an electron capture detector, Revision 3.1: Cincinnati, Ohio, National Exposure Research Laboratory of Research and Development, U.S. Environmental Protection Agency, p. 16.

Mulrooney, J.E., Wolfenbarger, D.A., Howard, K.D., and Goli, D., 1998, Efficacy of ultra low volume and high volume applications of fipronil against the boll weevil: Journal of Cotton Science, v. 2, p. $110-116$.

National Pesticide Telecommunications Network, 1997, Fipronil fact sheet, accessed May 20, 2002, at URL http://ace.orst.edu/info/npic/factsheets/ fipronil.pdf

Ngim, K.K., and Crosby, D.G., 2001, Abiotic processes influencing fipronil and desthiofipronil dissipation in California, USA, rice fields: Environmental Toxicology and Chemistry, v. 20, no. 5, p. 972-977.

Rhône-Poulenc, Inc., 1996, Fipronil: Research Triangle Park, N.C., Worldwide Technical Bulletin, p. 2.
Sandstrom, M.W., 1995, Filtration of water-sediment samples for determination of organic compounds: U.S. Geological Survey Water-Resources Investigations Report 95-4105, 13 p.

Schwartz, J.R., 2001, Jefferson County, Colorado mountain ground water resource study: Golden, Colorado, Jefferson County Colorado Planning and Zoning, accessed September 13, 2002, at URL http://206.247.49.21/ext/dpt/public_works/ planning/water/mgwrs-home.htm

Stout, M.J., Rice, W.C., and Ring, D.R., 2002, Integrated management of the rice water weevil: Louisiana Agriculture, v. 45, no. 1, p. 20-21.

U.S. Geological Survey, 2002, Water-quality data for South Platte River at Denver, Colo., 1998-2001: accessed October 2, 2002, at URL http:// waterdata.usgs.gov/co/nwis/qw

U.S. Environmental Protection Agency, 1996, Fipronil: Washington, D.C., Office of Prevention, Pesticides, and Toxic Substances, New Pesticide Fact Sheet, 8 p.

1997, Guidelines establishing test procedures for the analysis of pollutants (App. B, Part 136, Definition and procedures for the determination of the method detection limit): U.S. Code of Federal Regulations, Title 40, revised as of July 1, 1997, p. 265-267.

2001, FY2001 conventional pesticides

registration decisions: accessed May 21, 2002, at URL http://www.epa.gov/opprd001/workplan/ regdec2001.pdf 2002, Alternatives to chlorpyrifos: accessed May 20, 2002, at URL http://www.epa.gov/pesticides/ op/chlorpyrifos/alternatives.htm

Vilchez, J.L., Prieto, A., Araujo, L., and Navalon, A., 2001, Determination of fipronil by solid-phase microextraction and gas chromatography-mass spectrometry: Journal of Chromatography A, v. 919, no. 1, p. 215-221.

Zaugg, S.D., Sandstrom, M.W., Smith, S.G., and Fehlberg, K.M., 1995, Methods of analysis by the U.S. Geological Survey National Water Quality Laboratory-Determination of pesticides in water by $\mathrm{C}-18$ solid-phase extraction and capillarycolumn gas chromatography/mass spectrometry with selected-ion monitoring: U.S. Geological Survey Open-File Report 95-181, 60 p. 